\title{
Prognosis of heart transplant patients in Mashhad University of Medical Sciences
}

\author{
Mohammad Abbasi Teshnisi ${ }^{1}$, Farveh Vakilian ${ }^{1}$, Nahid Zirak $^{1}$, Alireza Sedaghat ${ }^{1}$, \\ Seyed Hamid Reza Hoseini Khah², Amir Hooshang Mohammadpoor ${ }^{2}$, Vahab Azmonfar ${ }^{1}$, \\ Farideh Golhasani Keshtan ${ }^{2}$, Masoumeh Rohani ${ }^{1}$, Reza Bagheri ${ }^{1}$, Abbas Ardehali ${ }^{3}$ \\ ${ }^{1}$ Lung Diseases Research Center, Mashhad University of Medical Sciences, Mashhad, Iran \\ ${ }^{2}$ Mashhad University of Medical Sciences, Mashhad, Iran \\ ${ }^{3}$ Thoracic Surgeon Ronald Reagan UCLA Medical Center, Santa Monica, USA
}

Kardiochir Torakochir Pol 2020; 17 (1): 33-38

\begin{abstract}
Introduction: Heart transplant is the ultimate treatment for patients with end-stage heart failure.

Aim: To assess 50 heart transplant patients for underlying diseases, transplantation outcome and mortality rate during a 5-year follow-up program.

Material and methods: Fifty heart transplant patients who underwent heart transplantation from 2012 to 2017 were assessed for underlying diseases, organ rejection, duration of hospitalization, extubation time, cardiac output and survival. Biopsy samples were obtained after surgery for evaluation of rejection.

Results: Dilated cardiomyopathy (DCM) and ischemic cardiomyopathy (ICM) were the most common underlying diseases with prevalence of $56 \%$ and $12 \%$, respectively. Significant improvement in ejection fraction was observed following heart transplant. Minimum and maximum extubation and hospitalization times were 3-408 hours and 1-51 days, respectively. Organ rejection evaluation 10 days after heart transplantation revealed that $50 \%$ of patients did not show any rejection while $10 \%$ had severe rejection. At 30 days post-operatively the number of patients with grade III rejection decreased to $2 \%$ while $56 \%$ of patients had no sign of rejection. The 5 -year survival rate was $66 \%$ while infection and arrhythmia were the most common causes of death.

Conclusions: DCM and ICM are considered the most prevalent underlying diseases in heart transplant candidates. Ejection fraction reached normal ranges following transplant, which provides good quality of life. Low incidence of severe acute rejection demonstrates the effectiveness of our immunosuppressive therapy. In the cases of increased rejection, the patient's immunosuppressive regimen was re-assessed accordingly.
\end{abstract}

Key words: heart transplant, heart failure, organ rejection, underlying disease, ejection fraction.

\section{Streszczenie}

Wprowadzenie: Przeszczep serca jest leczeniem ostatniej szansy u pacjentów ze schyłkową niewydolnością serca.

Cel: Ocena 50 pacjentów po przeszczepie serca pod kątem chorób podstawowych, wyników przeszczepu i wskaźnika śmiertelności w 5-letnim okresie obserwacji.

Materiał i metody: Pięćdziesięciu pacjentów, u których wykonano przeszczep serca w latach 2012-2017, poddano ocenie w kierunku chorób podstawowych, odrzucenia narządu, długości okresu hospitalizacji, czasu do ekstubacji, rzutu serca i okresu przeżycia. Po operacji pobrano próbki biopsyjne do oceny odrzucenia narządu.

Wyniki: Najczęstszymi chorobami podstawowymi w badanej grupie były kardiomiopatia rozstrzeniowa (DCM) i kardiomiopatia niedokrwienna (ICM), występujące z częstością odpowiednio $56 \%$ i $12 \%$. Po przeszczepie serca odnotowano istotną poprawę frakcji wyrzutowej. Minimalny i maksymalny czas do ekstubacji oraz okres hospitalizacji pacjentów wyniosty odpowiednio 3-408 godzin i 1-51 dni. Ocena odrzucenia przeszczepionego narządu przeprowadzona 10 dni po przeszczepie serca wykazała brak oznak odrzucenia u 50\% oraz wysoki stopień odrzucenia narządu u 10\% pacjentów. Po 30 dniach od operacji liczba pacjentów z III stopniem odrzucenia zmniejszyła się do $2 \%$, natomiast u 56\% pacjentów nie stwierdzono oznak odrzucenia. Wskaźnik 5-letniego przeżycia chorych wyniósł 66\%, a głównymi przyczynami zgonów były zakażenia i zaburzenia rytmu serca.

Wnioski: Najczęstszymi chorobami podstawowymi u kandydatów do przeszczepu serca są DCM i ICM. Po przeszczepie frakcja wyrzutowa osiagnęła przedział wartości prawidłowych, który zapewnia pacjentom dobrą jakość życia. Niski odsetek ostrych odrzuceń świadczy o skuteczności stosowanej przez nas terapii immunosupresyjnej. Przy nasilonych oznakach odrzucenia ponownie oceniano schemat leczenia immunosupresyjnego u danego pacjenta.

Słowa kluczowe: przeszczep serca, niewydolność serca, odrzucenie narządu, choroba podstawowa, frakcja wyrzutowa.

Address for correspondence: Prof. Reza Bagheri PhD, Lung Disease Research Center, Mashhad University of Medical Sciences, Mashhad, Iran, phone: +98 5138594083, e-mail: bagherir@mums.ac.ir

Received: 30.11.2019, accepted: 23.02.2020. 


\section{Introduction}

The first successful human-to-human heart transplantation was performed by Dr. Christiaan Barnard in 1967 [1]. According to United Network for Organ Sharing (UNOS) reports, 3408 heart transplants had been performed in the US by August 31, 2019. Professor Mohammad Hosssein Mandegar performed the first heart transplant in Iran in July 1993 at Shariati Hospital. As of May 2019, 213 more heart transplants have been performed at this center.

Heart transplant is the final treatment option for patients with end-stage heart failure, which could be the result of cardiomyopathies, heart valve or coronary artery diseases, pulmonary hypertension, ventricular arrhythmia, amyloidosis and congenital heart defects [2, 3]. Other risk factors associated with heart failure may include diabetes [4], HIV [5], myocarditis [6], hyperthyroidism, hypothyroidism [7] and hemochromatosis [8]. Despite the fact that heart transplantation is considered the ultimate therapeutic option for patients with end-stage heart failure, there are several risks associated with this procedure including surgery-related complications (infection, bleeding, stroke, generation of blood clots and heart attack) as well as postoperative complications including organ rejection, transplant coronary artery disease and immunosuppressant-derived side effects (infection, malignancies, diabetes, kidney disease and osteoporosis) [9]. However, organ rejection remains the major cause of mortality and patient's readmission after heart transplant. The International Society for Heart and Lung Transplantation (ISHLT) has established a standardized grading system for detecting cardiac rejection. This grading system consist of four major grades: Grade 0 represents no rejection, Grade I represents mild rejection, Grade II represents moderate rejection and Grade III represents severe rejection [10].

\section{Aim}

In the present study 50 patients received a heart transplant and were assessed for underlying diseases, risk factors, and transplantation outcome and mortality rate during a 5-year follow-up.

\section{Material and methods}

The study was approved by the institutional review board of Mashhad University of Medical Sciences and written informed consent forms were obtained from all patients. The present retrospective study was conducted at Imam Reza Hospital in Mashhad. 50 heart transplant candidates with end stage heart disease who received heart transplantation from June 2012 to October 2017 were included in this study. The first and second endomyocardial biopsies (EMB) were obtained 10 and 30 days after surgery. Histopathological evaluation of collected samples for detecting organ rejection was performed based on ISHLT guidelines.

\section{Immunosuppression protocol}

All patients received 3-drug immunosuppression according to our protocol. We used rabbit antithymocyte globulins for induction therapy. Azathioprine (GlaxoSmithKline) (4 mg/kg) was administered 1 hour before the operation and solumedrol (1000 mg) was infused upon release of the aortic cross-clamp. Rabbit antithymocyte globulin (1.5$2.5 \mathrm{mg} / \mathrm{kg} /$ day) was continued for 5 days after transplantation. Oral cyclosporine (Novartis, New Jersey) was started within 5 days or after renal functional recovery at dosages adjusted based on renal function and drug levels, which were maintained at trough values of $300-500 \mathrm{ng} / \mathrm{ml}$ during the first 3 post-transplantation months and $200-300 \mathrm{ng} / \mathrm{ml}$ at 1 year thereafter. Azathioprine (1-2 mg/kg/day) was prescribed after transplantation at dosages adjusted to maintain a white blood cell count of $4000-6000 / \mathrm{mm}^{3}$. Prednisone $(0.5 \mathrm{mg} / \mathrm{kg} / \mathrm{day})$ initiated on postoperative day 2 was gradually reduced to $0.2 \mathrm{mg} / \mathrm{kg} /$ day by the first month. Tacrolimus (FK-506) (Fujisawa, Japan) and mycophenolate mofetil (Cellcept) (Roche, Segrate, Italy) were used in cases of recurrent rejection or severe adverse reactions to cyclosporine or azathioprine, respectively. Since 2004, mycophenolate mofetil has been substituted for azathioprine as primary immunosuppression. To minimize nephrotoxicity, the cyclosporine dose was reduced to sustain a level of 250-350 ng/ml during the first 3 months after transplantation and $150-250 \mathrm{ng} / \mathrm{ml}$ at 1 year after transplantation.

\section{Rejection survey and biopsy protocol}

All patients were followed up 10 day after heart transparent, at Imam Reza Hospital. Patients in the scheduled biopsy group underwent a scheduled endomyocardial biopsy 10 days after heart transplantation in the ICU, and 1 , 2, 4, 8 months and one year after heart transplantation. During the follow-up period, 10 days after heart transplantation in the ICU, and 1, 2, 4, 8 months endomyocardial biopsies followed for 1 year, then they were performed yearly with coronary artery evaluations. Rejection was defined as a biopsy-proven pathological finding or clinical event leading to specific immunosuppressive intervention.

Patients' medical records were created including measurements of age, sex, height and weight, physical examination (patient's underlying disease, blood type, pre-operative diet, stomach, liver and kidney conditions, psychological state and dental health) and paraclinical findings (including PUMP time and ischemia times). Early and late postoperative complications, mortality and cause of death of all the patients who participated in the follow-up program were also included in the study. Patients who did not attend follow-up appointments were contacted via phone call.

\section{Statistical analysis}

Data analysis was performed using SPSS version 16 software. The $\chi^{2}$ and two-way $t$-test were used for evaluating non-continuous and continuous variables, respectively. A $p$-value of $<0.05$ was considered significant.

\section{Results}

Table I represents epidemiologic measurements of patients' age, weight and height. The average age, weight and 
height of patients who underwent heart transplantation as the receiver were $34.9,60.4 \mathrm{~kg}$ and $164 \mathrm{~m}$, respectively. The average age, weight and height of patients who underwent heart transplantation as the donor were 28.3, $95 \mathrm{~kg}$ and $166 \mathrm{~m}$, respectively (Table I). The frequency of state of organ capacity in the patients operated on were 5 (10\%) urgent and 43 (86\%) elective list.

Distribution of sex in receivers was 31 (62\%) male and 19 (38\%) female; in donors it was 40 (80\%) male and 9 (18\%) female (Table II).

Evaluating patients' underlying diseases prior to surgery revealed that dilated cardiomyopathy (DCM) was the most common underlying disease with prevalence of 28 (56\%) followed by ischemic cardiomyopathy (ICM) with prevalence of 6 (12\%), while diabetes with prevalence of 2 (4\%), and valvular cardiomyopathy (VCM), arrhythmogenic right ventricular cardiomyopathy (ARVC), mitral valve replacement (MVR), and restrictive cardiomyopathy (RCM) with prevalence of 1 (2\%) were also observed. Eight patients in this study did not have any underlying disease (Tables II, III, Figure 1).

Blood type determination of patients showed that $\mathrm{A}^{+}$ was the most frequent blood group type with prevalence of $32 \%$, followed by $B^{+}(26 \%), \mathrm{O}^{+}(22 \%)$ and $\mathrm{AB}^{+}(10 \%)$, while $A B^{-}, A^{-}, B^{-}$and $O^{-}$were the rarest blood group types with prevalence of $2 \%$.

Twenty-one (42\%) out of 50 patients were under treatment for weight loss or gain, 3 (6\%) were receiving medication for liver disease, 10 (20\%) had kidney disease, 16 (32\%) had dental decay and 5 (10\%) were under treatment for stomach disease. Echocardiographic assessment of patients before and after heart transplant showed significant improvements (42.55\%) in ejection fraction (EF) (Table IV, Figure 2).

Table IV represents extubation times (minimum 3 and maximum 408 hours), duration of admission to the ward (minimum 0 and maximum 17 days) and ICU (minimum 1 and maximum 51 days) (Table $V$ ).

Biopsy results showed 6 patients with moderate rejection (grade II), 11 patients with mild rejection (grade I) while 33 patients had no acute rejection (grade 0) (Table VI, Figure 3).

Of 50 heart transplants patients, the number of those who survived was 33 (66\%), and of those who died was 17 (34\%).

Ischemic times greater than 4 hours have been associated with increased mortality and greater than 6 hours have been considered prohibitive. In our study mean \pm SD ischemia time was $57.02 \pm 15.6$ minutes; minimum and maximum were 46 and 551 minutes.

Mean \pm SD pump time was $79.3 \pm 28.6$ minutes; minimum and maximum were 46 and 221 minutes.

The follow-up program after heart transplantation showed that 33 (66\%) patients survived while 17 (34\%) died within 5 years following the surgery (minimum 0 , maximum 2160 days with the average of 364.8 days). Causes of death are presented in Table VII.
Table I. Patients' demographic status

\begin{tabular}{lccc}
$\begin{array}{l}\text { Parameter } \\
\text { Receiver: }\end{array}$ & Age [years] & Weight $[\mathrm{kg}]$ & Height $[\mathrm{cm}]$ \\
\hline Minimum & 4.00 & 14.00 & 96.00 \\
\hline Maximum & 61.00 & 100.00 & 185.00 \\
\hline Mean & 34.9600 & 60.4082 & 164.1 \\
\hline Donor: & & & \\
\hline Minimum & 11 & 44 & 97.00 \\
\hline Maximum & 47 & 30 & 190 \\
\hline Mean & 28.3 & 95 & 166 \\
\hline
\end{tabular}

Table II. Patients' sex status

\begin{tabular}{lc} 
Receiver & \\
\hline Male & $31(62 \%)$ \\
\hline Female & $19(38 \%)$ \\
Donor & $40(80 \%)$ \\
\hline Male & $9(18 \%)$ \\
\hline
\end{tabular}

Table III. Distribution of different underlying diseases in patients

\begin{tabular}{lcc} 
Underlying disease & Frequency & Percentage \\
DCM & 28 & 56 \\
\hline No underlying disease & 8 & 16 \\
\hline ICM & 6 & 12 \\
\hline CHID & 2 & 4 \\
\hline Diabetes & 2 & 4 \\
\hline VCM & 1 & 2 \\
\hline ARVC & 1 & 2 \\
\hline MVR & 1 & 2 \\
\hline RCM & 1 & 2 \\
\hline Total & 50 & 100 \\
\hline
\end{tabular}

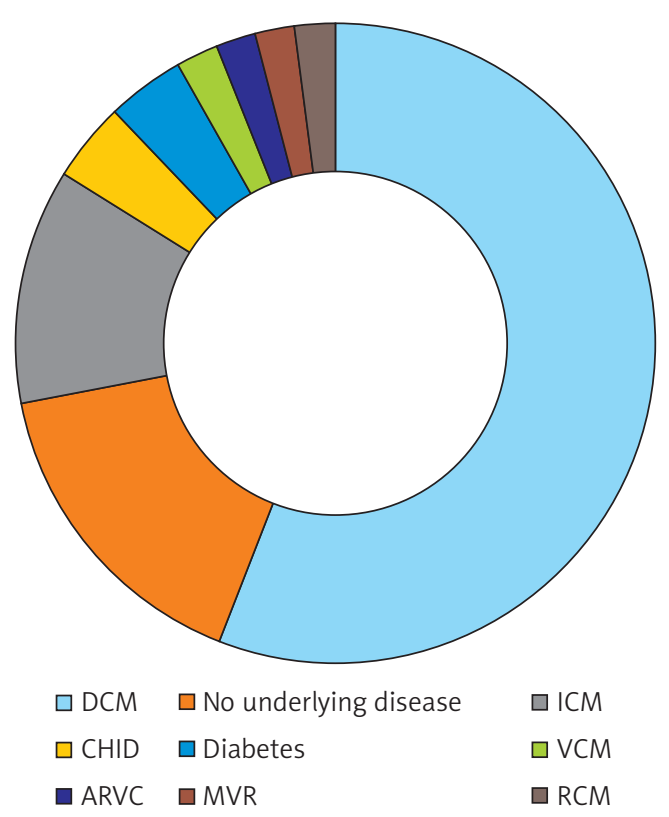

Figure 1. Distribution of patients' underlying diseases 
Table IV. Patients' EF before and after heart transplant

\begin{tabular}{lcc} 
EF & Mean \pm SD & P-value \\
Before surgery & $9.59 \pm 6.15$ & 0.0001 \\
\hline After surgery & $52.14 \pm 14.5$ & \\
\hline
\end{tabular}

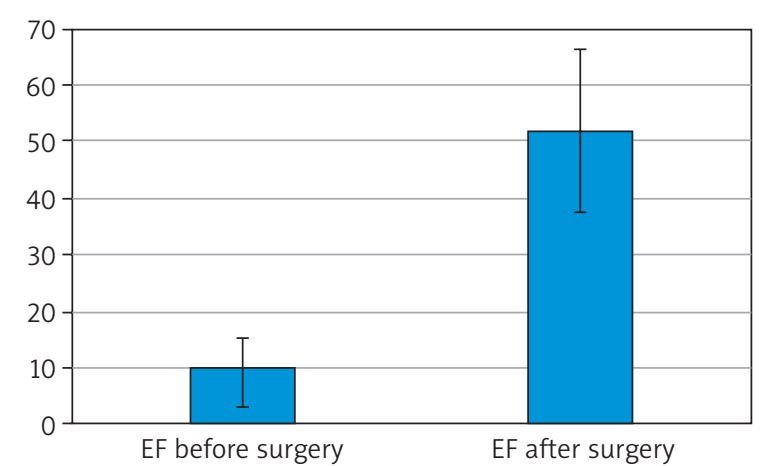

Figure 2. Improved cardiac EF after heart transplant

Table V. Extubation times and hospitalization duration

\begin{tabular}{lcc} 
Parameter & Minimum & Maximum \\
Extubation time [hours] & 3 & 408 \\
\hline ICU admission duration [days] & 1 & 51 \\
\hline Ward admission duration [days] & 3 & 17 \\
\hline
\end{tabular}

Table VI. Assessment of EMBs following heart transplantation

\begin{tabular}{lcccc} 
Variable & \multicolumn{2}{c}{10 days after surgery } & \multicolumn{2}{c}{30 days after surgery } \\
\cline { 2 - 5 } & Frequency & Percentage & Frequency & Percentage \\
Grade III & 0 & 0 & 2 & 4 \\
\hline Grade II & 6 & 12 & 2 & 4 \\
\hline Grade I & 11 & 22 & 14 & 28 \\
\hline Grade 0 & 33 & 66 & 32 & 64 \\
\hline Total & 50 & 100 & 50 & 100 \\
\hline
\end{tabular}

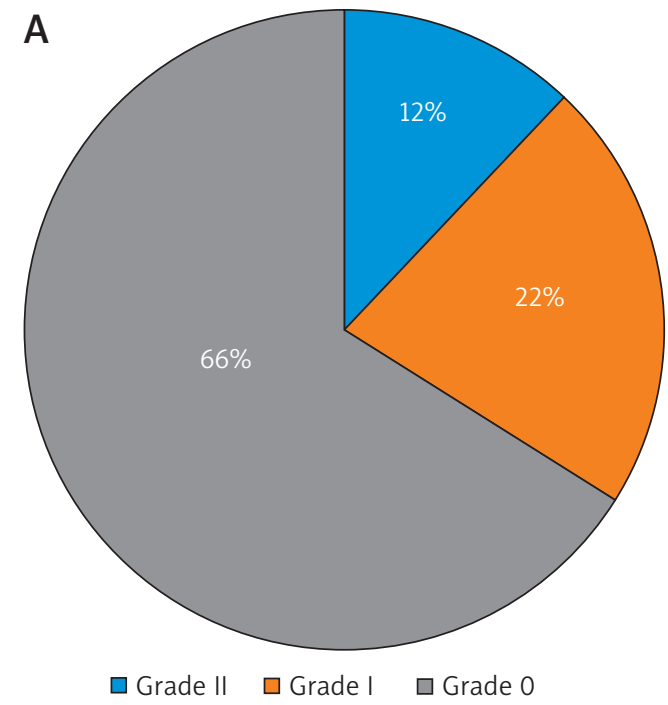

Figure 3. EMB 10 days (A) and 30 days (B) after surgery

\section{Discussion}

Heart failure can be defined as myocardial inability to provide enough blood flow to other organs in the body including the brain, lungs and kidneys. Heart failure (HF) in chronic kidney disease (CKD) is increasing, and it is necessary to develop optimal strategies for its detection, prevention, diagnosis, and management [11]. Heart failure can be the result of acute or chronic conditions caused by structural or functional abnormalities or a sudden overload. The main clinical hallmarks of heart failure are reduced heart contractility and subsequent pathological remodeling [12]. Cardiomyopathies subtypes include hypertrophic cardiomyopathy (HCM), ischemic cardiomyopathy (ICM), dilated cardiomyopathy (DCM), arrhythmogenic cardiomyopathy and left ventricular (LV) cardiomyopathy [13]. DCM is defined by enlargement and low contractility of the left ventricle (LV) in the absence of ischemic, congenital, valvular conditions or hypertension and is considered a major risk factor for heart failure [14]. ICM is described as the co-presence of heart failure and coronary artery disease $[15,16]$. In general, $54 \%$ and $45 \%$ of patients undergoing heart transplant are suffering from DCM and ICM, respectively [17]. In this regard, we also observed that DCM and ICM were the most common underlying diseases in our transplant patients. A previous study on underlying diseases of patients on the waiting list prior to heart transplantation revealed that patients with RCM, CHID, VCM and HCM are at higher risk of mortality awaiting heart transplant [18]. This report confirms our findings on low prevalence of patients with underlying RCM, CHID, VCM and HCM. Diabetes was another underlying disease which was detected in our patients. It is well accepted that diabetic patients are at higher risk of heart failure due to myocardial damage caused by ischemic or thrombotic conditions [19-22].

EF as an indicator of cardiac function, is an important element in evaluating heart transplantation outcome. A left ventricular ejection fraction of less than $40 \%$ is as-

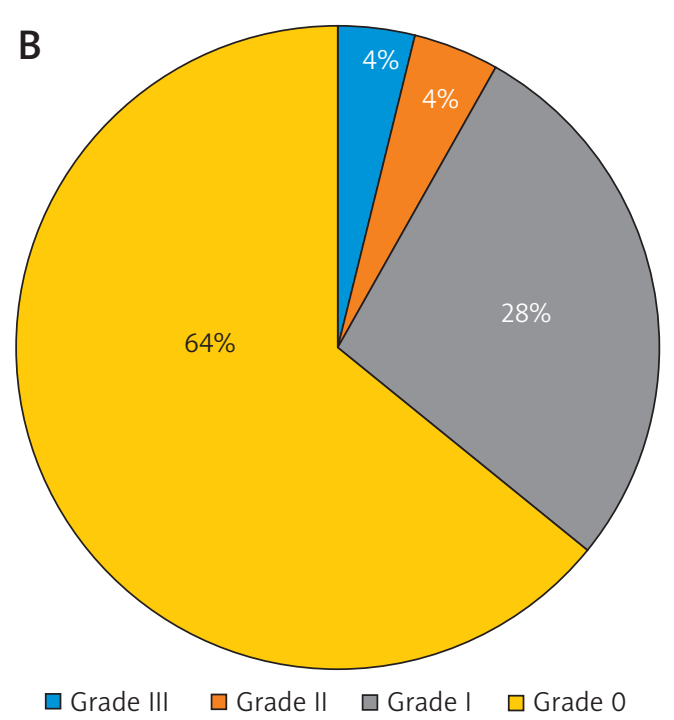


sociated with heart failure. The average EF of our patients after heart transplantation reached normal ranges, which shows significant improvement in patient's quality of life.

A recent UNOS-based study defined the prolonged length of stay (PLOS) in the hospital for patients undergoing heart transplantation as more than 25 days. Patient's length of stay (LOS) in hospital after heart transplantation depends on different clinical and non-clinical variables. Major risk factors include poor functional status, preoperative mechanical ventilation and extracorporeal membrane oxygenation, renal failure and donor-recipient sex mismatch [23]. Longer LOS correlates with higher mortality and morbidity rates; hopefully the average LOS in our patients was lower than 25 days.

Although heart transplant is considered the gold standard approach for end-stage heart failure patients, organ rejection remains the major challenge in this procedure's outcome. Donor organ rejection is the result of the recipient's cellular or humoral immune responses to transplanted heart and may occur as hyper acute (immediate and intraoperative organ rejection), acute (first week up to three months) and chronic (over many years following transplantation) rejection. EMB is one of the most commonly used approaches for diagnosis of acute rejection in patients receiving a heart transplant [24]. Based on our findings, the low incidence of severe acute rejection (4\% of patients) within 1 month following heart transplant demonstrates the effectiveness of our immunosuppressive therapy protocol. In the cases of increased mild rejection occurrence (grade I), the patient's immunosuppressive regimen was reassessed accordingly. However, due to the limited number of biopsy samplings (10 and 30 days post-operation) in our study, chronic and transient incidents of organ rejection may not have been detected in patients.

A good survival rate of $66 \%$ was observed in 5 years following heart transplant in our patients. Main mortality causes in our patients were arrhythmia, intra-operative hemorrhage, hypoglycemic shock and infection. Infection and arrhythmia were the most common causes of mortality. Infection is one of the most frequent causes of mortality in transplant patients, which is mainly due to consumption of immunosuppressive drugs [25-28]. Immunosuppressive therapy of transplant patients is a double-edged sword, in which insufficient administration of suppressant drugs may lead to early organ rejection, while on the other hand, high levels of these drugs can result in infection and malignancies. Two of our patients died from addiction and overdose and one patient died from refusing to take medications following heart transplant, which demonstrates the importance of patient education prior and after heart transplant.

\section{Conclusions}

Despite great advances in heart transplant strategies, major challenges remain to be addressed related to patient care, which can significantly affect the therapeutic outcomes. Patient education is an important determinant
Table VII. Causes of death for heart transplant patients following surgery

\begin{tabular}{lcc} 
Cause of death & Frequency & Percentage \\
Intra-operative hemorrhage & 1 & 5.8 \\
\hline Arrhythmia & 5 & 29.4 \\
\hline Hypoglycemic shock & 1 & 5.8 \\
\hline Infection & 4 & 23.5 \\
\hline Seizure & 1 & 5.8 \\
\hline Heart failure & 2 & 11.7 \\
\hline Rejection & 1 & 5.8 \\
\hline Drug overdose & 2 & 11.7 \\
\hline Total & 17 & 100 \\
\hline
\end{tabular}

with a great impact on patient's survival after receiving the new heart. It is essential that a comprehensive patient education program be established by health care providers prior and after heart transplant, which can clearly describe the importance of patient's self-care after receiving a new heart and that life-long self-care is as important as the heart transplant itself in the patient's prognosis. This program should include information regarding the urgency of appropriate drug consumption, attending scheduled checkups and daily repercussions for patients who underwent heart transplantation. Moreover, it is necessary to increase the number and availability of post-transplant health care centers to improve the quality of follow-up programs and patient accessibility.

\section{Disclosure}

The authors report no conflict of interest.

\section{References}

1. Cooper DKC. Christiaan Barnard - the surgeon who dared: the story of the first human-to-human heart transplant. Glob Cardiol Sci Pract 2018; 2018: 11.

2. Ponikowski P, Voors AA, Anker SD, Bueno H, Cleland JGF, Coats AJS, Falk V, González-Juanatey JR, Harjola VP, Jankowska EA, Jessup M, Linde C, Nihoyannopoulos P, Parissis JT, Pieske B, Riley JP, Rosano GMC, Ruilope LM, Ruschitzka F, Rutten FH, van der Meer P; ESC Scientific Document Group. 2016 ESC Guidelines for the diagnosis and treatment of acute and chronic heart failure: The Task Force for the diagnosis and treatment of acute and chronic heart failure of the European Society of Cardiology (ESC)Developed with the special contribution of the Heart Failure Association (HFA) of the ESC. Eur Heart J 2016; 37: 2129-2200.

3. Ziaeian B, Fonarow GC. Epidemiology and aetiology of heart failure. Nat Rev Cardiol 2016; 13: 368-378.

4. Rosano GM, Vitale C, Seferovic P. Heart failure in patients with diabetes mellitus. Card Fail Rev 2017; 3: 52-55.

5. Remick J, Georgiopoulou V, Marti C, Ofotokun I, Kalogeropoulos A, Lewis W, Butler J. Heart failure in patients with human immunodeficiency virus infection: epidemiology, pathophysiology, treatment, and future research. Circulation 2014; 129: 1781-1789.

6. Corsten MF, Schroen B, Heymans S. Inflammation in viral myocarditis: friend or foe? Trends Mol Med 2012; 18: 426-437.

7. Klein I, Danzi S. Thyroid disease and the heart. Circulation 2007; 116: 1725 1735.

8. Kremastinos DT, Farmakis D. Iron overload cardiomyopathy in clinical practice. Circulation 2011; 124: 2253-2263.

9. Birati EY, Rame JE. Post-heart transplant complications. Crit Care Clin 2014; 30: 629-637. 
10. Stewart S, Winters GL, Fishbein MC, Tazelaar HD, Kobashigawa J, Abrams J, Andersen CB, Angelini A, Berry GJ, Burke MM, Demetris AJ, Hammond E, Itescu S, Marboe CC, McManus B, Reed EF, Reinsmoen NL, Rodriguez ER, Rose AG, Rose M, Suciu-Focia N, Zeevi A, Billingham ME. Revision of the 1990 working formulation for the standardization of nomenclature in the diagnosis of heart rejection. J Heart Lung Transplant 2005; 24: 1710-1720.

11. House AA, Wanner C, Sarnak MJ, Pińa IL, McIntyre CW, Komenda P, Kasiske BL, Deswal A, deFilippi CR, Cleland JGF, Anker SD, Herzog CA, Cheung M, Wheeler DC, Winkelmayer WC, McCullough PA; Conference Participants. Heart failure in chronic kidney disease: conclusions from a Kidney Disease: Improving Global Outcomes (KDIGO) Controversies Conference. Kidney Int 2019; 95 : 1304-1317.

12. Rockman HA, Koch WJ, Lefkowitz RJ. Seven-transmembrane-spanning receptors and heart function. Nature 2002; 415: 206-212.

13. Elliott P, Andersson B, Arbustini E, Bilinska Z, Cecchi F, Charron P, Dubourg O, Kühl U, Maisch B, McKenna WJ, Monserrat L, Pankuweit S, Rapezzi C, Seferovic $P$, Tavazzi L, Keren A. Classification of the cardiomyopathies: a position statement from the European Society Of Cardiology Working Group on Myocardial and Pericardial Diseases. Eur Heart J 2008; 29: 270-276.

14. Bozkurt B, Colvin M, Cook J, Cooper LT, Deswal A, Fonarow GC, Francis GS, Lenihan D, Lewis EF, McNamara DM, Pahl E, Vasan RS, Ramasubbu K, Rasmusson K, Towbin JA, Yancy C; American Heart Association Committee on Heart Failure and Transplantation of the Council on Clinical Cardiology; Council on Cardiovascular Disease in the Young; Council on Cardiovascular and Stroke Nursing; Council on Epidemiology and Prevention; and Council on Quality of Care and Outcomes Research. Current diagnostic and treatment strategies for specific dilated cardiomyopathies: a scientific statement from the American Heart Association. Circulation 2016; 134: e579-e646.

15. Kim CH, Tofovic D, Chami T, Al-Kindi SG, Oliveira GH. Subtypes of heart failure in autoimmune diseases. J Cardiac Failure 2017; 23: S22.

16. McNally EM, Mestroni L. Dilated cardiomyopathy. Circulation Res 2017; 121: 731-748.

17. Botta DM. Emedicine. Heart Transplantation 2016.

18. Hsich EM, Rogers JG, McNamara DM, Taylor DO, Starling RC, Blackstone EH, Schold JD. Does survival on the heart transplant waiting list depend on the underlying heart disease? JACC Heart Fail 2016; 4: 689-697.
19. Stratton IM, Adler Al, Neil HA, Matthews DR, Manley SE, Cull CA, Hadden D, Turner RC, Holman RR. Association of glycaemia with macrovascular and microvascular complications of type 2 diabetes (UKPDS 35): prospective observational study. BMJ 2000; 321: 405-412.

20. MacDonald MR, Petrie MC, Varyani F, Ostergren J, Michelson EL, Young JB, Solomon SD, Granger CB, Swedberg K, Yusuf S, Pfeffer MA, McMurray JJ; CHARM Investigators. Impact of diabetes on outcomes in patients with low and preserved ejection fraction heart failure: an analysis of the Candesartan in Heart failure: Assessment of Reduction in Mortality and morbidity (CHARM) programme. Eur Heart J 2008; 29: 1377-1385.

21. Kenny HC, Abel ED. Heart failure in type 2 diabetes mellitus. Circ Res 2019; 124: 121-141.

22. Dokken BB. The pathophysiology of cardiovascular disease and diabetes: beyond blood pressure and lipids. Diabetes Spectrum 2008; 21: 160.

23. Crawford TC, Magruder JT, Grimm JC, Suarez-Pierre A, Patel N, Sciortino CM, Zehr KJ, Mandal K, Tedford RJ, Russell SD, Conte JV, Higgins RS, Cameron $\mathrm{DE}$, Whitman GJ. A comprehensive risk score to predict prolonged hospital length of stay after heart transplantation. Ann Thorac Surg 2018; 105: 83-90.

24. Sisson S, Jazzar A, Mischke L, Cooper DK, Zuhdi N. How many endomyocardial biopsies are necessary in the first year after heart transplantation? Transpl Int 1996; 9: 243-247.

25. Jung SH, Kim JJ, Choo SJ, Yun TJ, Chung CH, Lee JW. Long-term mortality in adult orthotopic heart transplant recipients. J Korean Med Sci 2011; 26: 599-603.

26. Wilhelm MJ. Long-term outcome following heart transplantation: current perspective. J Thorac Dis 2015; 7: 549-51.

27. Lindenfeld J, Miller GG, Shakar SF, Zolty R, Lowes BD, Wolfel EE, Mestroni L, Page RL $2^{\text {nd }}$, Kobashigawa J. Drug therapy in the heart transplant recipient. Circulation 2004; 110: 3734-3740.

28. Norum HM, Michelsen AE, Lekva T, Arora S, Otterdal K, Olsen MB, Kong XY, Gude E, Andreassen AK, Solbu D, Karason K, Dellgren G, Gullestad L, Aukrust P, Ueland T. Circulating delta like Notch ligand 1 is correlated with cardiac allograft vasculopathy and suppressed in heart transplant recipients on everolimus-based immunosuppression. Am J Transplant 2019; 19: 10501060. 